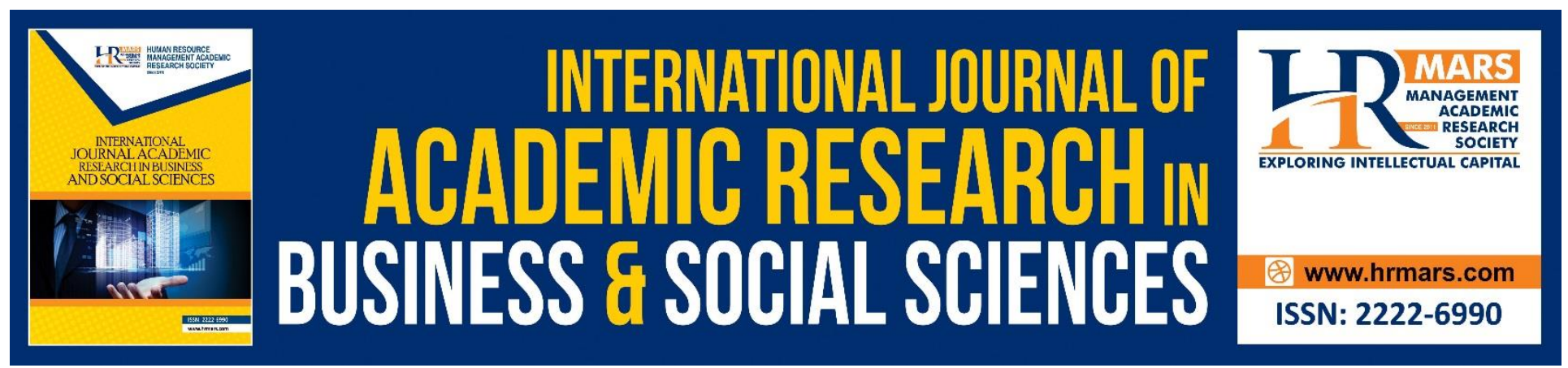

\title{
The Culture Factor in Women's Empowerment in Leadership
}

\author{
Catherine Jendia
}

To Link this Article: http://dx.doi.org/10.6007/IJARBSS/v9-i2/5543

DOI: $\quad 10.6007 /$ IJARBSS/v9-i2/5543

Received: 17 Jan 2019, Revised: 25 Feb 2019, Accepted: 04 March 2019

Published Online: 06 March 2019

In-Text Citation: (Jendia, 2019)

To Cite this Article: Jendia, C. (2019). The Culture Factor in Women's Empowerment in Leadership. International Journal of Academic Research in Business and Socal Sciences, 9(2), 264-282.

\section{Copyright: (c) 2019 The Author(s)}

Published by Human Resource Management Academic Research Society (www.hrmars.com)

This article is published under the Creative Commons Attribution (CC BY 4.0) license. Anyone may reproduce, distribute, translate and create derivative works of this article (for both commercial and non-commercial purposes), subject to full attribution to the original publication and authors. The full terms of this license may be seen at: http://creativecommons.org/licences/by/4.0/legalcode

Vol. 9, No. 2, 2019, Pg. 264 - 282

Full Terms \& Conditions of access and use can be found at http://hrmars.com/index.php/pages/detail/publication-ethics 


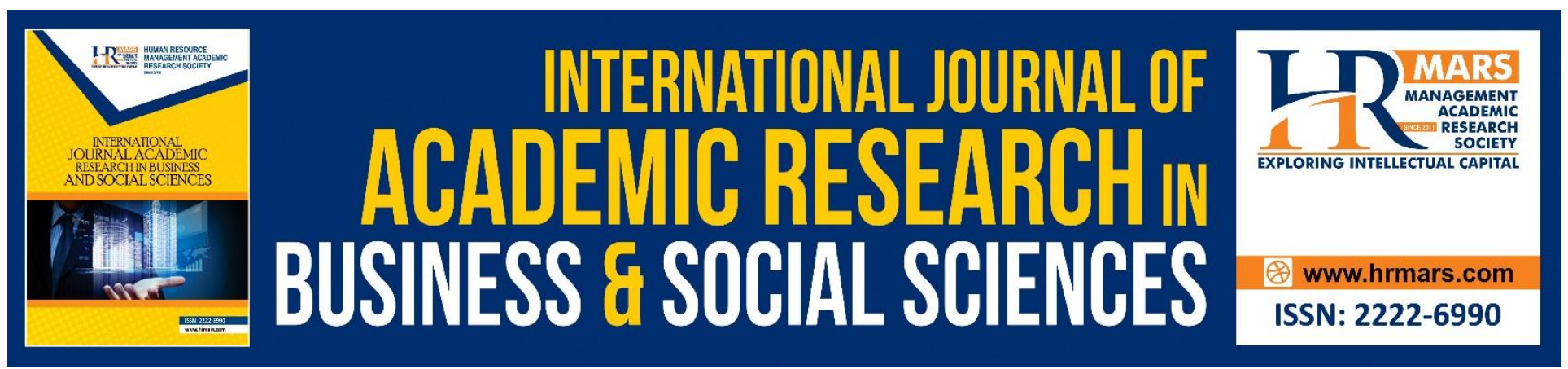

\title{
The Culture Factor in Women's Empowerment in Leadership
}

\author{
Catherine Jendia, (Dr.) \\ Department of Religion and Peace Studies, College of Humanity and Social Sciences, Makerere \\ University, P.O. Box 7062, Kampala, Uganda \\ Email: cjendia@chuss,mak.ac.ug
}

\section{Abstract}

The research investigates the topic, The Culture Factor in Women's Empowerment in Leadership in Ugandan Context. Whereas many scholars view African cultural practices as hindrances to women's empowerment in leadership, the paper argues the contrary. The research argues that within culture(s) are opportunities that support women's empowerment in leadership. The purpose of the research was to identify and highlight opportunities for transformation of mindset, behaviors and practices.

The study approach is qualitative supported by desktop method. The principal result is that opportunities exist within culture for women's empowerment in leadership. The study concludes that indeed there are inherent potential opportunities within culture that support women's empowerment in leadership and makes three recommendations.

Keywords: Culture, Women, Gender, Leadership, Empowerment

\section{INTRODUCTION}

\section{Objectives of the Study}

The paper examines, The Culture Factor in Women's Empowerment in Leadership in Uganda. The principal purpose of this research is to explore positivity inherent in culture that could possibly support women's empowerment in leadership. Also, the study seeks to find new opportunities in culture that could be beneficial to leaders and policy makers for addressing gender inequalities. The specific Objectives include: (i) finding out the opportunities and contribution of culture towards gender parity, (ii) identifying positive cultural practices, values, attitudes and institutions that enhance women's empowerment for increased active participation in leadership activities and roles. The paper comprises: introduction, research problem, Justification of the Study, Review of Related Literature, Research Methodology, and International Context to the Study, Findings of the Study, Discussion, and Implications for Leadership, Conclusion and Recommendations. 


\section{The Research Problem}

This study recognizes that women in Uganda registered some gains in the spheres of political leadership and economics. The major concern of this research work is that whereas women appear to enjoy a measure of gender equality in politically and economically, a critical analysis of the situation shows that many women especially in rural households still lack empowerment in leadership. In nearly all levels of society gender based inequalities are evident. Women face marginalization in the corridors of power both politically and socially, in the market place and even in academia. The prevalence of gender based violence is clear symptom of lack of women empowerment and lack of gender equality in Ugandan society. It is clear, that gender equality remains a farfetched ideal as disparities loom large across the country all because of lack of women's empowerment for in leadership resulting from oppressive cultural practices and traditions. This study therefore seeks to explore opportunities within culture for women's empowerment in leadership.

\section{Justification of the Study}

The significance of this study is fourfold. Firstly, it explores the utility of traditional participatory systems which provide opportunities for developing or building on the existing structures to address leadership challenges in relation to gender inequality. Secondly, the study underscores the need for trained persons as effective game changers, developers and practitioners of culture based approaches in gender related programs in communities. Thirdly, the study brings to the attention of leaders that in the diverse cultures of Uganda, there are potentials for gender empowerment and equity. Therefore, understanding cultural frameworks within which people operate, organize themselves, and solve problems could provide inspiration in their investigative efforts. The ability of development partners such as Non Governmental Organizations (NGOs), Civil Society Organizations (CSOs) to view traditions and customs as important values that unite and hold centres of societies together are a step in the right direction. Hence, it is important to critically examine cultural practices to identify positive elements necessary for women's empowerment programs. Fourthly, in line with Mbiti, (1986) the goal of culture is to train, develop, and provide morals to guide human social behaviour.

The rationale of is of the study is fourfold. Firstly, leaders both governments and the private sectors and policy makers can utilize the findings of this investigation in gender-mainstreaming in participatory programs. Secondly, this study provides inspiration to researchers, scholars, and leaders to continually seek opportunities existing within cultures for transformation of gender relations. Thirdly, it provides insights for developing and promoting more inclusive approaches for empowering women and men, thereby increasing opportunities for building more comprehensive, integrated, productive and multicultural coexistence in Uganda. Fourthly, gender issues are fast becoming a global concern. Therefore, there is a need for government to be seen as addressing glaring issues such as lack of women empowerment in leadership, gender based violence and inequalities in an effort to achieve more inclusive social order in Ugandan society. 


\section{Review of Related Literature}

The analysis of literature shows that culture is an inhibitive force which effectively dis-empowers women. In this study, culture is defined as learnt gender roles and behaviors from a given social environment. Kinias Zoe and Heejung Kim (July 2011), agreed that culture has great influence on how men and women think about themselves in terms of their gender roles. In Ugandan context, men receive cultural cues about expectations to be tough, masculine and objective and unemotional as a measure of masculinity. Hence, gender disparities are one of the most gradual and destructive forms of societal injustices which in effect compound other forms of inequalities. Mbiti John (1986), Zimbalist Rosaldo and Louise Lamphere (1993) and Florence Kyoheirwe Muhanguzi (2006) all agreed that cultural perceptions and social behaviors promote gender inequalities which in effect militate against women's empowerment in leadership. They maintain that traditional male occupations include: police forces, truck driving, construction, engineering, factory work, leadership and management etc still prevail in organizations. On the other hand gender-based inequalities are largely cultural based than religion suggesting interplay of other factors hindering women's empowerment and emancipation. Concurring with that school of thought, Marilee Karl (1995) argued that a great many factors affect women's social participation, including their households, economic status, traditional customs and attitudes which either promote or inhibit their participation in leadership.

In the Ugandan Context, among the over 63 social or tribal groups traditional female occupations comprise: secretarial work, housewifery, waitressing, housekeeping, cooking, teaching, and nursing and that still remains the status quo. To add salt to injury, the media (Radio, Television and print media) frequently reinforce the mentioned traditional practices, roles and perceptions. Therefore, the literature review reveals that indeed culture has negative influence on women. Hence culture is largely an agent of female bondage and oppression.

However culture is not the only factor that militates against women's empowerment in leadership. The literature analysis clarifies that culture stands out as a divisive factor between women and men. Where a society fosters conservative attitudes towards women's participation in activities outside the home female social roles are greatly limited and their contributions to development undermined by lack of recognition. Most importantly, analysis of the literature highlights a school of thought that views culture and attendant beliefs including customs, traditions and religious interpretations as unchangeable (AWID, 2015). This mental framework gives culture and society enormous influence on gender roles.

Undoubtedly culture affects individuals and social groups positively or negatively. Although previous studies depict culture as a significantly negative force denying women opportunities for empowerment in leadership, little prominence has been given to exploring opportunities for transformation within culture that support women's empowerment in leadership, hence the rationale for this research. Therefore, this study seeks to fill this research gap and contribute significantly to existing knowledge. 


\section{Research Methodology}

The research methodology is qualitative. The choice of qualitative approach is based on its descriptive suitability for handling the problem under investigation, thereby enabling accurate analysis of words, for example, reporting informants' views and in a natural setting (Creswell, 1998). Qualitative research is understood as an approach of investigation based on distinctive methodological techniques for exploring social phenomena or human problems. Majorly desktop method involves review of documents such as books, reports, articles; archives formed the main source of data collection. The analytical process includes coding, editing, interpretation and discussion.

\section{International Context to the Study}

In its quest to achieve sustainable development globally, the United Nations (UN), an umbrella body that brings together over 193 countries, launched several initiatives. Hence, the study is premised on several United Nations Conventions and initiatives. To this end, many United Nations' international institutions made gender equality a priority for development of democratization processes. These initiatives include, the Beijing Conference of 1995, which for example, served as a platform for action and was revised in June 2000 at the $23^{\text {rd }}$ United Nations General Assembly. The resolutions were as follows: Firstly, The General Assembly encouraged governments to specifically set and use both short and long term goals that define timeframe such as quota system in view of increasing women's participation in political leadership. Secondly, the United Nations Security Council formulated Resolution 1325. The resolution 1325 focused on the role women can play in peace building in conflict situations around the world. Thirdly, international mandates such as the Convention for Elimination of All Forms of Discrimination against Women were formulated and adopted by member countries. Fourthly, the General Assembly drew the Millennium Development Goals whose expected development target timeline was 2015. However by the end of 2015, most African countries, Uganda inclusive were at varying levels of implementations of the millennium development goals suggesting that the targeted development levels fell short of expectation.

In September 2015, the millennium development goals were overtaken by sustainable development goals whose time frame will be 2030 . The UN member countries realized that total elimination of poverty and related forms of deprivations require combine interventions and strategies for improved health, education, reduction of gender disparities which in effect drive economic growth while addressing the challenges of climate change and working to preserve oceans and forests of the world. The sustainable development goals captured several women related issues particularly, promotion of gender equality and women's empowerment, reduction of child mortality rates, improvement of maternal health to reduce maternal death rates and combating of HIV/Aids, elimination of Malaria and related diseases like tuberculosis. The implementation of the set goals by UN member countries is expected to bring about gender balance in all levels of public life. Accordingly, governments were encouraged to domesticate the said international initiatives especially the sustainable development goals, and to develop implementation strategies in view of enhancing growth socially, economically, and politically. By comparison, the African Union adopted the international agenda on gender equality and women's empowerment by the United Nations and declared 2015 a year of women's empowerment in line with Africa's development target of 2063. The declaration was recognition that women are indeed backbones and pillars of African societies and specifically so in the Great lakes region of East Africa. Discussion of international context of the study leads to the research findings. 


\section{Findings of the Study}

It should be pointed out that in Uganda nearly all communities are patrilineal. This means that existing customs and traditions are male oriented. The male sex is elevated to a superior position in the society while females are viewed as inferior, weak and passive which in effect dis-empower women in leadership.

\section{The Negative Role of Culture in Women's Empowerment}

The concerns about gender inequalities are not only uniquely a Ugandan but global problem. In July 2010 at a high-level United Nations' meeting on the Economic and Social development was focused on sustainable development goals whose target problem was gender inequality, women's empowerment and culture. One of the panelists, Kavita Ramdas, underscored the role of harmful traditions and practices in promoting gender inequalities when she said that:

The culture of suppression and dehumanization of women is one that is universally shared. [She argues] that even if we don't want to acknowledge it, because we think we have laws in place that make it different in the West, the truth is that our young women and our young men grow up with assumptions about what it means to be a woman, in this or any other cultures that are still profoundly degrading of us [women] as human beings and that is something we have to all work to change (Kavita Ramdas, 2010).

The research findings also demonstrate that besides culture, there is interplay of other inhibitive factors such as illiteracy and conservative mental framework which make the change difficult from the outside (Irin Bokova, 2010).

The issues raised in the quote suggest that culture is oppressive to women and that oppression is universal in nature meaning it cuts across the human race. There are still cultures whose practices degrade and dehumanize the female gender. In the Ugandan context, female genital mutilation is rampant in communities like the Sabin and sections of the Karamojong to mention but a few.

\section{Positive Role of Culture in Women's Empowerment}

As mentioned before, culture is a double edge sword because it affects individuals and groups both negatively and positively. The discussion on the negative role of culture in Women's Empowerment now focuses on the idea that culture can promote women's empowerment. In this regards, selected gendered institutions have been identified as follows: African family, Institution of Marriage, Polygenic Relationships, Kinship, Female Rulers and Decision Makers, Women and Health, Women and Economy and Social status of women in culture.

- The African Family

The African family is one of the gendered cultural institutions because it includes both women and men. What is referred to as the African family system is that it is largely extended in character although the family is increasingly becoming nuclear in character. Since an extended family brings up an aggregate of 10-20 women and men, boys and girls, young and old together, it provides suitable forum necessary for women's empowerment. Empowered women could then rightfully claim their human rights and influence socially, economically, and politically. If both nucleus and extended 
family systems are transformed into agents of positive socialization, the status quo could be reversed significantly in favour of women and their increased participation in leadership. It should be noted that the extended family is essentially not a conjugally constituted one. It is rather a consanguinebased family system built around blood relationships. This means that the family is not based on gender as sexual differentiation and determinant of category. Rather it is progeny. However, progeny itself is valued in terms of the ability to sustain and reproduce for purposes of ensuring viability and sustainability of a lineage, clan or community. John Mbiti (1986) argued that the African family includes children, parents, grandparents, uncles, aunts, other relatives living and dead both from father's and mother's side. Each person is expected to live in or as part of a family. The members of a family are bound by blood or by marriage, but most importantly by shared human experiences of living together. ${ }^{14}$. In the family survival skills, hierarchies of roles based on gender, age, and degree of kinship are taught and learnt.

- Institution of Marriage

The institution of marriage is very important and there is pressure from family and community on all able bodied young men and women to get married. Although marriage is the union between man and woman, it is more the union of families and clans. For this reason instances of divorce were less rampant then. The institution of marriage as gendered institution is fundamental for sustainability of families and communities. In Uganda marriage is a measure of a man or woman's self-worth, manhood, wealth, and social status. A normal mature male or female is expected to marry and form his or her own family. A person who is not married is regarded a second-class human being and is not worthy of respect. Marriage is even more important to women because it adds value to women as mothers thereby gaining social identity. A critical analysis of the institution of marriage demonstrates that women can achieve some form of social identity through their husbands and children. Therefore, marriage is considered the foundation of the family and the core of society. As such women are a great part of life's equation. They are an essential component of families and communities.

Although majorities of cultures give women little or no recognition in society even when they are married, some men tend to measure their social status and success in relation to women. Given the rampancy of polygamous relationships, a great majority of women (over $75 \%$ ) depend on their children for emotional and financial support than on their husbands. In the Ugandan context, the payment of bride price contributes to the expansion of social networks of relationships necessary for the harmony of families and communities. Women seemingly enjoy socio-economic advantage through payment of bride price. However, the pressure exerted on the groom and his family to pay dowry to the family of the bride apparently continues to perpetrate gender inequalities. The use of bride price though significant in the institution of marriage, poses a serious challenge to women's empowerment in leadership. This is because the practice a paying dowry apparently suggests that women are a commodity of trade in human beings. This can only mean that the slave trade of the $19^{\text {th }}$ century prevails moreover voluntarily. As women are traded out, their families are ensured of reversing poverty because often the pride price comprises head of cattle. The males in the family are assured of dowry should they achieve readiness to get married. 
- $\quad$ Polygenic Relationships

In Uganda, as in the Great Lakes Region, patriarchy is the norm in polygenic relationships. Polygamy is rampant and the practice favors men rather than women. This means that dominant men can marry more than one wife who may live in separate location and semi-autonomous household. According to Sylvia Tamale (1999) patriarchy in Uganda is not the western type of patriarchy. Women have no political powers even in households. While men appear to control women, manage gender relations, and provide support for the welfare of their wives and families. In practical terms women enjoy a relative degree of autonomy in carrying out their productive, reproductive, economic and social roles in their individual homes. Women's empowerment, as argued by scholars like Stamp (1986), should best be understood as bargaining with patriarchy.

\section{- $\quad$ Kinship Relationships}

The study revealed that kinship offers another opportunity for women's empowerment in leadership and gender equality. According to Mbiti's perspective (1986) kinship is very important in all aspects of African life. Kinship alliances refers to those who belong together with a common reason to unite as one people and claim a common origin with many other shared commonalities. Essentially kinship represents networks of social relations including: husbands, wives, co-wives, mothers, fathers, mothers-in-law ("mothers"), fathers-in-law ("fathers"), stepparents, stepchildren and biological children. In polygenic relationships, co-wives are expected to care for their husbands' children from other marriages. Typically women can use kinship ties to access resources from both their husbands' lineages and their paternal lineages. In these social networks, leadership roles are clearly defined through heredity or personal merit, experience, and wisdom.

Kinship provides yet another opportunity within culture for women's empowerment in leadership. An analysis of kinship institution shows embedded social relationships. The Kakwa of Uganda is a case in point. Kinship relations provide women with flexibility and far reaching opportunities because cultural relationships accord women access to various types of resources including farmland, cash, borrowing and lending facilities, as well as information. The empowered and enlightened women could most certainly use cultural opportunities such as kinship to promote their welfare and socio-economic status and even defend their human rights which in effect enable them to assert and claim their rightful place in society. This explains why both women and men often draw on kinship relations to gain or defend property rights; to recruit labour at low cost; to gain access to livestock, and even cash payments through bride wealth. Thus kinship as a component of culture opens yet new opportunities for women to the extent that they increasingly gain access to resources: land, capital, cash, and employment etc.

The findings reveal a paradigm shift in gender roles in Uganda. Women's work places are no longer the kitchens. Women are beginning to gain increasing participation in leadership in society especially as members of parliament. Women Heads of state in Africa, namely, Ellen Sirleaf Johnson of Liberia and Joyce Banda of Malawi, still accounts for 3.7\% only but that is a step in the right direction. While $14.8 \%$ of Africa's vice presidents are women, with Uganda's Specioza Wandera Kazibwe being the first female to pioneer on the African continent. 
- Female Rulers and Decision Makers as part of the "Historical Memory"

In the Great Region, as elsewhere in pre-colonial Africa, the different cultures provide some limited forms of participation of women in political leadership. The form of political participation varies according to the intimate workings of the different cultures and the distinct arrangements between the sexes. Historical memory of the region indicates that gendered forms of authority existed in the $19^{\text {th }}$ century and even earlier. Queen mothers, for instance, played a significant political role in traditional monarchical systems that constitute the cultural heritage of many communities (Tarikhu Farrar, 1997: 579). African women wielded political power in many ways. In Buganda for example, autonomous queens and influential queen mothers are the most obvious evidence that women had significant political powers. The office of the Namasole, meaning queen mother, contributed much more actively towards the practice of good governance. The powers and prerogatives of the Namasole culturally supersede those of all the other smaller clan chiefs. The extent of queen's autonomous power is demonstrated in 1862, when king forbade anyone from visiting the European explorer, J. H. Speke who was camped in Mengo, Buganda's capital. One of the ministers of the queen visited the explorer anyway. The queen mother's lands were spread through the Buganda kingdom and were exempted taxation by the king. As a woman, the land ownership provided the queen(s) with material base independent of the king. Moreover, people who lived in her territories reportedly served the queen and not the king.

In segmentary societies, such as the Luo of Kenya, and the Alur of Uganda, women used to be diviners and mediums, enjoying the prerogatives of kings. In Buganda queen mothers were kingmakers alongside men. The queen mothers frequently used their material resources (land, power, taxes, and alliances) to secure the Ganda throne for a favoured son. The queen mother ensured that the crown prince and heir apparent exercise good leadership and governance. The king was guided to serve and meet the interests and needs of the people he governed. The queen mother was ultimately one of the royal advisers. This suggests that women opinions and inputs were valued and sought after.

The turmoil that engulfed most of East Africa in the $19^{\text {th }}$ century fundamentally transformed gendered institutions. Political organization that was gender sensitive ceased to be operational. The succession of weak rulers to power and the growing political and economic powers of wealthy chiefs such as Stanislaus Mungwanya reduced many kings in the Buganda region to figureheads or ceremonial leaders. In the rapidly changing political order the queen mother no longer appear to exercise meaningful influential roles in politics because their authority was directly linked to that of a king. In addition, the growing grip of patriarchy constitutes one of the most important factors perpetuating gender imbalances and injustices. As earlier mentioned before, Ugandan societies are basically patriarchal in nature. This means that males dominate decision-making positions and processes, economic and power resources and the strategic aspects of social life. This is the case in both the traditionally segmentary societies which had no central governments of Kingships such as the Luo Lugbara of Uganda and the centrally governed kingdoms of Buganda, Bunyoro, Toro, etc. 
- Women and Health

In traditional African context, healing is considered both a spiritual realm in a physical terrain. Families and whole communities always require spiritual deliverances, healing services of spiritual; leaders and mediums. These African specialists have clienteles from far and near. Earlier studies by scholars like Mbiti (1969) show that in most cases, native doctors both women and men, also doubled as herbalists who administer medicine and treat ailments of the communities. Many communities recognize the spiritual powers that some women possess, especially as witchdoctors, priestesses. The priest and priestesses provide linkages between the spiritual and physical realms. They were the eyes and spokes persons of the deities and gods. That many communities recognize women's contribution to social development as medicine specialist and spiritual agents demonstrate that African cultural institutions have within them resources and opportunities for gender empowerment. It is clear that in every cultural community, God endows both men and women with unique talents and capacities to support and sustain social well-being. For the existing social parameters to change with regard to gender equity cultural constraints embedded in daily experiences of people such as taboos and biases and prejudices should be systematically tackled. Only then can attitudinal change in favour of empowerment of both women and men be achieved.

\section{- Women and Economy}

It is common knowledge that agriculture constitutes the backbone of most of African economies Uganda inclusive. In many communities women are key agricultural producers. They contribute much of labor force in food and cash crop production. Studies show that women produce $80 \%$ of the food grown for survival. Unfortunately, women's efforts often go unrecognized and their inputs are often not integrated in policy programs that enhance their agricultural productivity. Customs often prohibit women's complete or total independent control of finances and assets or gains from agricultural labour and food production. The point being made is that the removal or reduction of gender-based inequalities could greatly enhance the full participation of both women and men in agricultural activities. In addition to labor contributions, women are increasingly becoming farm managers and heads of farm households.

Today women are increasingly employed both in the formal and informal sectors including industries. However, the few who are in the formal sector often cluster at the bottom ranks of the organizational hierarchy as clerical officers, receptionists, support staff, becoming susceptible to retrenchment and sexual harassment. The majority of women in the industrial setting are employed in the informal sector requiring less specialized skills and limited capital investments which offers flexible working schedule that allow women to combine their employment/business with domestic demands. The fact of the matter is that women are largely still marginalized in the economy. However, in the event that the economy is threatened by high population growth, drought, decline of soil fertility, depletion of forest for firewood, charcoal, and timber, as well as water pollution all of which leads to climatic change --then women can be brought on board, perhaps not as subjects to be consulted, but as problems to be solved. Women are instructed in reproductive health programs and they are blamed for poor farming practices and deforestation as they try to meet their reproductive obligations. 
The findings reveal that one of the cultural obstacles to women's economic empowerment in leadership is the denial of their right to ownership and control of resources, especially land. Men on the other hand seem to have the prerogative over land, cattle and other treasured assets of the family. For example, women are denied a fair share of the output of their labor in agricultural production, especially in both food and cash crop production. It is no wonder that many women view culture as one major factor in creating and perpetrating gender inequality. Culturally, the normative tenure is that land is communally owned. In Uganda, women are cultural custodians of agricultural wealth and environmental knowledge. Women use this knowledge to sustain agricultural practices, ecosystems, biodiversities and conservation of local flora and fauna as an integral part of their daily living. In an attempt to improve agricultural practices, environmental management and increase development prospects some scholars initiated a number of programs directed at accelerate women's active roles without any effort and to tap into the rich culturally knowledge. More commonly women's existing knowledge and practices merely remain invisible. This underscores the importance of initiating leadership and economic empowerment programs from the point of view of the existing cultural knowledge and practices in a community (Stamp, 1986).

In rural Uganda, land is still regarded a community property. In this regard, customary land tenure applies. The sale of land of communal land even when a person has individual needs or has the right of ownership over it is always viewed negatively by the community as a sign of irresponsibility and betrayal. The (July/August, 2007) land clashes in Bulisa District in Northwestern Uganda are cases in point. Thus cultural control can be used as a basis for achieving reduction if not a total elimination of gender inequalities. This requires sensitization of communities about domestic rights of women and children with regard to property especially land. In most Ugandan cultures women have the right to use customary land of the clan to which they have been married into. The concept of communal ownership then is a positive starting point for improving women's rights over ownership of property and hence their empowerment in leadership.

From the study, women face a challenge of lack of political will by those who direct the economy to translate women's economic and cultural work into monetary value and rewards in order to better gauge their contribution. This could be another means by which societies recognize women's significant contributions to economic growth. Often the burdensome domestic roles played by women such as child bearing and rearing, food growing and preparation, even though treasured by many, are considered priceless. There is negative valuation attached to these roles, but the monetization of every aspects of life today calls for a paradigm shift not only in Uganda but in Africa at large.

\section{- Social Status of Women in culture}

In the social context, women exercise gender roles in the setting of a patriarchal society. However, this patriarchy is not the western type of patriarchy in which domination is absolute. In Uganda women enjoy relative autonomy. They occupy special position within the society. Accordingly women are anchors of families or "the heart of the home" (Lebeuf, 1963). In a number of communities the words "woman" or "sister" has dignified meaning that is closely connected to the concept of "motherhood," which suggests respect and intimacy. For instance, among the Alur of northwestern Uganda, "sonship" 
(u-mego) or "daughtership" (nya-mego) are designated feminine terms denoting motherhood "mego." The greatest profanity and taboo a person can commit is against the dignity of motherhood (Southall, 1970). This illustrates that the concepts of womanhood and sisterhood in a number of communities are better understood in the context of the extended family.

\section{Positive Efforts in Emancipating Women Politically, Economically and socially}

The domestication of international conventions and initiatives has seen the rise of women activism against cultural practices especially female genital mutilation common in some parts of Uganda. Genital mutilation is a cultural practice and an example which proves how culture de-empowers women in leadership. To reduce cultural grip on women in society, gender activists such as Joy Kwesiga, Sylvia Tamale, and Miria Matembe (high profile educators, politicians, and legislators) increased gender activism. This favorable development hinges on decisive move by government through adoption of affirmative action policy. The affirmative action involved establishing mechanisms for provision of equal opportunities to women and men in politics, economics, education, religion and social life. Programs of affirmative action sought to increase a critical mass especially of women. This was done in recognition that women are actively involved in various fields of life and there is a historical gap between women and men. The expectation was that empowered women should be better equipped to exercise significant leverage in policy decision-making and legislative activities which are essentials of leadership.

The implementation of the policy of affirmative action was practically executed through creation of district quota system in political constituencies for women at all levels of government from the grassroots including parliament. Accordingly, a 1.5 points preferential treatment for women enrolling in government funded tertiary institutions was awarded girls to increase women's enrollment and to close gender gaps. The affirmative action policy was also implemented in appointments of women to high level government positions, for example, in the cabinet, judiciary and State commissions such as Uganda National Roads Authority, Inspectorate of Government, Uganda Revenue Authority, Speaker of Ugandan and East African parliaments and (Tamale, 1999). Furthermore, government created a Ministry for Gender and Social Development, a Directorate for Women's Affairs; and established academic training programs such as Women's and Gender Studies at the Makerere University (one of the largest public Universities in East Africa. Sylvia Tamale and Miriam Matembe among others began to question and challenge male domination which appears to be virtually embedded in all sectors of life in Uganda.

The precedence set by government encouraged some employers to begin applying affirmative action and principles of equal opportunities in their management of human capital and resources. The application of a combination of gender activism and affirmative action by both governments and women's groups such as Women Parliamentarians, International Organization of Women Lawyers (FIDA), and Forum for African Women Democracy and Education (FAWE), etc accounts for the levels of successes registered in addressing gender inequalities. In Makerere University, today, the numbers of students' enrollment stand at $50 \%$ females and $50 \%$ males or more. Frequently females outnumber males in many of the course units offered in the Humanities. 


\section{Discussion}

In this section, the discussion focuses on the positivity within culture which support paradigm shift in cultural mental framework for promoting increased women's empowerment in leadership. The purpose of the study was to explore positivity inherent in culture that support women's empowerment in leadership. One of the objectives was to find out the opportunities for gender parity by identifying positive cultural practices, values, attitudes and institutions. By examining cultural gendered institutions (i-viii), the study makes an argument that that there exist within cultures opportunities and practices that fundamentally support for women's empowerment in leadership.

Another window of opportunity for paradigm shift is in the area of cultural rights. Cultural rights are important because they significantly protect the rights of each person individually and communally which allows women to express their humanity, world views and meanings and interpretations they assign to human existence. This can be achieved through language development, beliefs, values, convictions, knowledge and art (Stein, 2015). In as far as culture distributes roles, privileges, rights, utilization, access and ownership of resources including land and property, it is possible for a given culture to rethink and make a paradigm shift with regard to norms and values thereby providing new interpretations to gender roles, land use and property rights. Thus unlocking opportunities in culture requires paradigm shift involving changes in mental framework to recognize the need for gender equilibrium and sharing of responsibilities between women and men, wives and husbands, mothers and fathers, brothers and sisters.

In the context Uganda, land and property are bases for socio-economic livelihood and provide platform for gaining financial, social and political powers and related resources necessary for empowerment in leadership. This view point is corroborated by Shaheed Farida (2012) who argued that women's cultural rights to land and property are essentially a demand for equal opportunities in all aspects of life: social and culturally, politically, economically, civil and health. The findings show that the demand for equal opportunities by women remains a farfetched dream without the intervention government. Kadaga Rebecca, a Member of Parliament for Kamuli and a two times Speaker of the national Parliament of Uganda rightly observed that government of Uganda needs to work towards increasing numbers of women in positions of influence at national levels and within other state institutions. Increasing the numbers would translate into equal opportunity for women's participation in leadership and decision making processes.

Recent statistics shows that, in Uganda women constitute more than half the population of 35,000,000 persons. The findings of this study further reveal changing trends towards improvement of relationship between men and women with regard to shared roles and resources both in formal and informal sectors indicating substantial achievements. It would seem that women are beginning to play significant roles in leadership in both politics and business. Specioza Wandera Kazibwe was the first female vice president not only in Uganda but in whole of Africa. Rebecca Kadaga Alitwala and Margret Ziwa are speakers of parliament at national and regional levels. Betty Bigombe is a seasoned conflict mediator and was instrumental in the peace building process in Northern Uganda. There are a growing number of women serving as cabinet ministers and diplomats. Elsewhere in Africa, Ellen Johnson Sir 
Leaf and Joyce Banda stand out heads of states in Liberia and Malawi. Women are representing their governments as heads of diplomatic missions and ambassadors. Elizabeth Napeyok Paula, Hyuha Samali Dorothy, Nimisha Jayant Madhvani are a cases in point. However, despites the gains registered so far, the situation of the majority of women remains culturally economically, politically, and socially pathetic. The growth from gender activists perspective seems to be concentrated at the higher levels of the elite, the educated, and the middle class, with little trickle down effects on the vast majority of women particularly at the grassroots level.

The study argues that statistics alone do not translate into substantive representation of women. However, the great number of women population still does not translate into political and economic muscle in the country. Consequently, women continue to face challenges related to gender imbalances in political representation and in decision-making processes. Legally you find that sometimes, the same constitution that enfranchises women also legitimizes certain practices that are discriminatory in nature against women under customary law, for instance, the recognition of patriarchal control of resources in households (UN Common Database, 2004).

With regard to the Family as gendered institution, the research reveals that within the family the centres of power are significantly diffused. In many communities the fundamental organizing principle within the family is seniority, where seniority implies the social ranking of persons based on their chronological age, social influence and personal experiences. Therefore, the family as a microcosm of society serves as a fundamental core unit for socialization. On the other hand, the family is also a place where ideas and practices of gender inequalities such as domestic violence, gender based discrimination, and other social injustices are practiced and sustained and implemented. Therefore is clear that the cultural process of gender dis-empowerment begins in the family where practically all socialization processes begin.

The study recognizes that the existing model of cultural socialization appears to be based on incorrect assumption that women are passive subjects of patriarchal societies. This mental framework tends to ignore the structural and situational obstacles that hinder the reversal of gender roles. Individual "condescendingly benevolent" fathers and "assertively enlightened" mothers are beginning to share gender roles resulting in improved gender relations. Tamale (1990) agrees that women need to learn early in life at home, in schools, and industry how to assert themselves regardless of the domestic socialization processes. However, the expected outcomes on the women and children are not significantly felt because the larger society, its social institutions such as families, laws and practices do not provide the necessary environment for women's empowerment in leadership. In modern times, there are also many activities outside the domestic households whose effects tend to infringe on early childhood socialization of females.

Also the effectiveness of Affirmative Action as one of the platforms for gender activism is facing serious challenge especially with regard to education which is viewed as a critical tool for women's empowerment in leadership. The affirmative action yielded some tangible results. There is increased enrolment of women and girls particularly in tertiary institutions like Universities. In recent times, many 
highly placed women leaders, who invariably were outspoken and assertive in the public arenas like parliament include: Winnie Kizza, Betty AOL Ochan, Ingrid, Proscovia Salaam Nsuba, Cecilia Ogwal and Winnie Byanyima, and Bako Christine among others are cases in point. The research underscores the need for continued increased participation of women in education in order that the quest for women's empowerment in leadership is understood and championed properly. The inclusion of women in various socio- political and economic institutions can accelerate meaningful positive changes for improved gender relationships in the society by providing equitable opportunities for both men and women.

\section{Implications of the Research for Leadership}

The implication of this research for leadership is that the process of women's empowerment involves developing and giving equal opportunity to the powerless to gain access and control of Ugandan society. The concept of women's empowerment in leadership challenges existing power structures and power relations. Power as envisaged in the context of empowerment is threefold. (i) Power involves accessing and controlling material resources such as finance, land, human capital, and money. (ii) Power includes intellectual resources such as knowledge, information, ideas and access to sources of knowledge. (iii) Power consists of ideology, that is, the ability to generate, propagate, sustain and institutionalize a set of beliefs, values, attitudes and behaviours. This calls for gender activists, policy makers and stakeholders to consolidate the extended family by investing more resources to enhance the institution of the family since it is a fundamental centre for gender socialization and gender empowerment. Therefore as a cultural institution, the family is the most suitable and effective agent for addressing gender inequalities in the Uganda.

Related to the family is the practice of paying bride price on girls and women which is a cultural commerce in which women are the essential commodity of exchange. Such practice systematically strips women of their social privileges to the extent that they cannot claim right to ownership and control even of their own children to whom they subscribe half of the biological genetic characteristic or traits. The implication for women is that this cultural commerce reduces women to merchandise which are sold and bought at will. Thus, it becomes extremely difficult for a woman who is bought as if she were property to claim equal status with her buyer and boss because a property can never have equal rights with its owner. Therefore, the cultural practice of bride price payment is fundamentally a tool for women's insubordination and entrenchment of their human rights and freedoms. If Ugandan leaders desire effective governance performance, then there is need to recognize the glaring facts that as long as women's concerns and interests remain unaddressed or ignored, there can be no political and socio-economic transformation. However, the study gives hope in view of the institution of marriage. It is clear that marriage as a cultural gendered institution could possibly serve as one of the strategies for women's empowerment in leadership and gender activists should use the family as platform for advocating for increased women's rights and empowerment in leadership.

Still in relation to marriage, polygenic relationships provide another opportunity for women's empowerment in leadership. The high prevalence of incidences of Women Headed Households in modern times cannot only be explained in terms of the sex ratio of the population but also by the 
cultural household autonomy that many women enjoy. This could be used to reduce women's dependence on men, thereby increasing their voice, political power and ultimately cut back on prevalence of gender inequalities. This implies a shift in balance of power in marital relationships. Thus, women do have opportunity for empowerment in leadership even when polygenic relationships are prevalent. Now it is becoming possible for women to own property or share in a communally owned clan land. In modern times, women make very important decisions regarding their households. In the event that male dominance turns violent and wives can no longer bear spousal maltreatment, culture provides that such women return to their parental households. This explains why women easily assume the role of a family head in communities. While men have apparent powers over women, the wives practically run the show in households. Whereas culture tended to be inhibitive to women's empowerment and gender equality, the form of patriarchal practice in Uganda can provide a springboard for driving concerns of women's empowerment in leadership.

The research revealed that cultural education is significant in as far as it provides training and skills. As Mbiti (1986) agreed that the goal of culture is to develop members of society through discipline, education, and training. Emphasis is placed on proper, acceptable behaviour attained through instruction and training for both men and women to ensure responsible membership and sustainability of communities. This educational process emphasises traditional norms, values, and customs which must be inculcated and transmitted to all youths of a given social group. However, the effect of culture on women's social development leaves a lot to be desired. One of the shortcomings of cultural education is that it encourages preferential treatment to males at expense of females. Boys have unlimited opportunities that enable them access to community and national resources much more than the girls. Therefore boys tend to have more advantages even in formal education because men are the ones who participate in decision making in public affairs. The problem is that men are still perceived as pillars of society. However, in modern times the growing enrolment of females in primary, secondary and tertiary levels is an indicator of changing gender relations. It can be argued that formal education is fast becoming the key for women's liberation from cultural bondage.

\section{Conclusion and Recommendations}

In line with the major finding, the study concludes that even as culture is oppressive to women and cultural grip apparently hold women in bondage, this tyranny is not absolute because there exist within culture some antidotes for curing the problem. The antidotes are the opportunities for positive transformation which the study set out to identify and highlight. Most importantly, the conclusion draws attention to the existing opportunities within cultures for empowerment of women even in leadership. Although Uganda has numerically diverse cultures, resources are available that provide opportunities for women's empowerment in leadership. The said resources are embedded in gendered institutions were the focus of this study. The identified gendered institutions and traditional practices examined in this research demonstrate that a lot of opportunities exist within culture that can be used for empowering not only women but others marginalized groups to bring about holistic transformation politically, economically, and socially. 


\section{Theoretical and Contextual Contribution of the Research}

In this section, the research discusses theoretical and contextual contribution of the study. The research argues that the theoretical and contextual significance women's empowerment in leadership depends on process and agency. Anju Malhotra (2003) agreed that all efforts to empower women should take into account the implications for policy actions particularly at family levels. While the research focused on opportunities and transformation of cultural institutions, it is prudent to note that only gendered cultural institutions that support patriarchal principle should be targets of transformation. Systemic transformation of cultural institutions identified in this study is paramount. On the other hand, the concept of agency (Anju, 2003) denotes that women's empowerment in leadership is long overdue requiring rapid action plans. This entails that women must be active participants in the process of the desired change research advocates. The agency of the situation calls for women to rise and embrace the challenge of their lack of empowerment in leadership. This means women need to realize their own potential and capabilities as change agents on issues affecting them. Thus empowerment involves demand for facilitation, accountability, participation as well as mobilization of those who are in disadvantaged positions.

In the Ugandan context, the role of government in women's empowerment is critical. In general terms, African governments are chief custodians of all public resources. Therefore, there is need for governments and multilateral organizations to promote policies that strengthen gender equality through various means, including legal and political reform, and interventions to give women (and other socially excluded groups) greater access to resources. Whereas political, social, and economic resources are often critical for women's empowerment, resources in themselves are not sufficient. Women's individual and collective abilities to recognize and utilize resources in their own interests are equally important. Having discussed the concepts critical to women's empowerment in leadership, this research is significant because it contributes new knowledge to research and in the local context, the research draws attention and promotes paradigm shift from culture as tool of oppression and dehumanization of women to culture as loaded with opportunities for positive social transformation.

\section{Recommendations}

The study makes three recommendations as the way forward for expanding examination of the available opportunities within culture for women's empowerment especially in leadership. To begin with, the research has identified a number of positive African cultural elements that support women's empowerment in leadership.

- Since the research problem in question is women's lack of empowerment in leadership resulting from inhibitive cultural practices which limit their participation in leadership politically, economically, and socially, this characterizes it a typical African problem. The responsibility and solution to the problem lies squarely with African leaders and their people. In view of the stated research problem, the study recommends further research into gendered cultural institutions to better understand opportunities for positive paradigm shift in respect of women's authentic rights as human beings and their legitimate contributions to society. Further research into gendered forms of authority and institutions such the 
family, queen mother, kinship alliances, creates demand for more information and offers a practical solutions which in effect increases opportunities for enlightenment and transformation especially decision making, legislation. However, the push for cultural change should have as its starting point the cultural assumptions, values, norms, beliefs and attitudes already existing within a community.

- The study recommends that women themselves should champion the cause of their empowerment in leadership. Women parliamentarians in the various leadership positions in governments should engage in activism by becoming spokespersons and change agents advocating for women's empowerment and recognition of women's rights. The implementation of this recommendation will benefit women greatly as they would unlock hidden talents and synergy innate in them. Women's actions would change the perception that they passive and weak recipients of benefits.

- As East African region works towards regional integration, the member states would do well to pursue the issue of women's empowerment in leadership collectively. Hence the study recommends that regional leaders of East Africa seriously consider investing more resources in the African family systems and traditional institutions that have political and socio-economic significance. Governments could develop policies that support transformation and viability of families while promoting gender equity.

\section{REFERENCES}

\section{Books}

Conrad, P. K. (2000). Anthropology, Boston: McGraw-Hill.

Creswell, J. W. (1998). Qualitative Inquiry and Research Design. Thousand Oaks, CA: SAGE Publication.

Ivy, D., \& Backlund, P. (2000). Exploring Gender Speak, Boston: McGraw-Hill.

Lebeuf, A. (1963). The Role of Women in the Political organization of African Societies, in Denise Paulme, ed., Women of Tropical Africa. Berkeley: University of California Press.

Mbiti, S. J. (1991). Introduction to African Religion. London: Heinemann Educational Books.

Mbiti, S. J. (reprinted 1986). Introduction to African Religion. London. Alyward Shorter.

Sahlins, M. (1976). Culture and Practical Reason. Chicago, IL: University of Chicago Press.

Stamp, P. (1986). "Kikuyu Women's Self-Help Groups: Toward an Understanding of the Relation between Sex-Gender System and Mode of Production in Africa", in Claire Robertson and Iris Berger, eds., Women and Class in Africa, New York: Africana Publishing.

Southhall, A. W. (1970). Rank and Stratification among the Alur and other Nilotic peoples.

Tamale, S. (1999). When Hens Begin to Crow: Gender and Parliamentary Politics in Uganda. Kampala: Fountain Publishers. 


\section{Internet Sources}

Chandler, D. \& Njoki W. (2002). Indigenous Gendered Spaces: An examination of Kenya, in Jenda: A Journal of Culture and African Women Studies: 2 (1). https://www.jendajournal.com/vol 2.1/chandler-wane.html. Accessed $3^{\text {rd }}$ November, 2018

Cristina, M. (2015). Gender Equality, Sustainable Development \& Women's Human Rights. Español: Association for Women's Rights in Development (AWID), https://twitter.com/AWID/status/576393222282416129. Accessed May 24, 2018.

Ebila, F. \&. Muhanguzi, K. Florence (Eds) (2006). Women, Culture \& Creativity (Gender Worlds Series), Department of Women and Gender Studies. Kampala, Uganda. Women's Worlds.

Kinias, $Z$ \& Hee, J. Kim (June 10, 2011). https://www.researchgate.net/publication/241648527_Culture_and_gender_inequality_Psychologi cal_consequences_of_perceiving_gender_inequality, journals.sagepub.com/doi/full/10.1177/1368430211408940.

Marilee, K. (1995). Women and Empowerment Participation and Decision Making. Journal of Development in Practice, Vol 5 (4), Taylor \& Francis. http://www.tandfonline.com/doi/abs/10.1080/0961452951000157414/journalCode=cdip20.

Accessed May 242017.

Shaheed, F, (1986 spring). The cultural articulation of patriarchy: legal systems, Islam and women. South Asia Bulletin; 6 (1):38-44.

Southall, A. W. (2004). Alur society: a study in processes and types of domination. Alur Society: A Study in Processes and Types of Domination. Cambridge: W. Heffer \& Sons Ltd., Pp. 396. Available at https://www.cambridge.org/core/journals/africa/article/alur-society-a-study-in-processes-andtypes-of-domination-by-a-w-southall-cambridge-w-heffer-sons-ltd-nd-pp-396L1C4BDB8272D59A91777E221CC3984F0A

Tarikhu, F. (1997). The Queen mother, Matriarchy, and the Question of Female Political Authority in Pre-colonial West African Monarchy. Journal of Black Studies, 27 (5), 579-597. https://doi.org/10.1177/002193479702700501 Accessed 24 November, 2018.

United Nations (2004). Ranking in relation to Gender Equality in Parliament. http://globalis.gvu.unu.edu/indicator. Accessed 16 $6^{\text {th }}$ November 2018. 